\title{
Assessing the evolution of primary productivity at distal sections from Cretaceous-Paleogene mass extinction
}

CLAUDIA SOSA MONTES DE OCA ${ }^{1}$, MARTA RODRIGOGÁMIZ $^{2}$, YIZHOU HUANG ${ }^{1}$, KYLE W.R. TAYLOR ${ }^{3}$, CHRIS J. HOLLIS ${ }^{4}$, FRANCISCA MARTÍNEZ-RUIZ ${ }^{5}$, FRANCISCO J. RODRÍGUEZ-TOVAR ${ }^{2}$, JOSE MANUEL CASTRO ${ }^{6}$, MARÍA LUISA QUIJANO ${ }^{7}$ AND RICHARD D. PANCOST ${ }^{1}$

${ }^{1}$ University of Bristol

${ }^{2}$ Universidad de Granada

${ }^{3}$ Elementar UK Limited

${ }^{4}$ GNS Science

${ }^{5}$ Instituto Andaluz de Ciencias de la Tierra

${ }^{6}$ Departamento de Geologia, Universidad de Jaen

${ }^{7}$ University of Jaén

Presenting Author: claudia.sosamontesdeoca@bristol.ac.uk

The Cretaceous/Palaeogene Boundary (KPgB) represents one of the five major mass extinctions in Earth's history, and determining the nature of associated environmental change and biotic recovery is critical for understanding that event as well as the history of life on our planet. We compared changes in organic matter inputs using biomarkers ( $n$-alkanes, acyclic isoprenoids, hopanes and steranes) in a set of distal sections, spanning the KPgB. These include the Agost in Spain, midWaipara River (MW) in New Zealand and the previously published data from Stevns Klint, Kerguelen Plateau (Site 738) and Walvis Ridge (Site 1262). The five selected sections exhibit sample-to-sample and TOC variability but minimal differences in the biomarker assemblages between pre- and post-KPgB, suggesting a rapid recovery of the non-fossilizing phytoplankton community at distal sites. Despite the persistence of life, the organic matter source is rather variable immediately after the impact event. At Agost, variations in the concentrations and distribution of the high-molecular-weight (HMW) $n$-alkanes and terrestrial-aquatic ratios (TAR) indicate an increase in the absolute and fractional abundance of terrestrial plant-derived organic matter just after the impact event. This co-occurs with an apparently transient decline in marine productivity, indicated by a decrease of low-molecular-weight (LMW) $n$-alkane (or fatty acids at the lower thermal maturity MW section), pristane and phytane concentrations and the sterane/hopane ratio $[\mathrm{S} /(\mathrm{S}+\mathrm{H})]$. Some but not all of these variations occur in the Mid Waipara section. Thus, the KPgB impact did affect environmental conditions and non-fossilizing algal communities even in distal sites, although these organisms appear to have rapidly recovered. 